\title{
Factors Affecting Implementation of ISO 9001:2015 in manufacturing Sector
}

\author{
Zohaib Khan Pathan'*, Yusri Bin Yusof ${ }^{1}$, Nor Haslinda Binti Abas², Anbia Adam¹, Yazid Saif ${ }^{1}$ \\ ${ }^{1}$ Faculty of Mechanical and Manufacturing Engineering, Universiti Tun Hussein Onn Malaysia (UTHM) 86400 \\ Parit Raja, Batu Pahat Johor, Malaysia \\ ${ }^{2}$ Faculty of Civil Engineering and Built Environment, Universiti Tun Hussein Onn Malaysia, 86400 \\ Parit Raja, Batu Pahat, Johor, Malaysia
}

\begin{abstract}
ISO 9001 mainly thrust on the commitment of top management of the organization as far as quality management system is concerned, as per the guidelines it is

the duty of top management to define a crystal clear polity for quality maintenance and also there should be clarity of responsibility and authority among the people involved in the same. Main objective of this paper is to identify the significant factors which barriers in implementation of ISO 9001:2015. In depth literature was conducted from where 29 general factors were found. A survey (Qualitative) was conducted from top managerial officials from manufacturing sector to determine significant factors. On basis of mean value total 11 significant factors were found which were related to manufacture sector in Pakistan. This study will be helpful for the managerial staff and officials to control identified factors for implementation of ISO.
\end{abstract}

Keywords

Factors, ISO 9001:2015, Manufacturing sector, Implementation.

\section{Introduction}

ISO (International Organization for Standardization) is one of the apex agencies for providing guidelines for the smooth functioning and benchmarking of different industries around the globe. As of now there are more than 18000 standards in the list and as stated by the agency itself ISO 9000 series is the best benchmarking system, this statement is based on the fact that this series of ISO is having about 22 guidelines for maintaining the quality standards. This overall system of standardization is governed and controlled by the technical committee (176) of ISO. This series of ISO 9001 mainly thrust on the commitment of top management of the organization as far as quality management system is concerned, as per the guidelines it is the duty of top management to define a crystal clear polity for quality maintenance and also there should be clarity of responsibility and authority among the people involved in the same. Then on the other hand it also demands for proper communication, management of available resources and clear/details documentation of the systems. At the next level it also suggests about the control of all the operational processes i.e. from production of final sales of goods and even the detailing of after sale service.

Any of the given organization that is conforming the application of ISO 9001 series in their respective organizations is required to state a commitment of continuous improvement in the available systems, perform internal audits at regular intervals and evaluate the performance of overall systems as and when required, this has to be done for the betterment and allowing for preventive actions.

\section{Application of PDCA}

The cycle of PDCA holds four basic components related to quality confirmations i.e.

- Plan

- Do

- Check, and

- Act

This system is liable to present a clear understanding of the prevailing processes and interaction between any number of given systems, as far as they are related to quality.

This cycle of PDCA is used and reused by the organizations of all size and shapes i.e. all the public and private sector concerns irrespective of their size, all the manufacturing, service and process industries.

As far as the acceptance and knowledge of ISO 9001 is concerned, it can be said that the agencies have maintained the standards after understanding the customer needs and related requirements. At the next level same has been forwarded to the respective organizations so that they can follow the same in their respective systems, in this way the acceptance of ISO 
9001 has increased and reached worldwide. This system of standardization has increased the credibility of the organizations who are following it and are having the requisite certification from the agency. Here it is important to mention that the schedule of ISO 9001 has been revised three times from the time of its inception in 1987 i.e. in 1994, 2000 and 2009. These changes called for amendment in the understanding of guidelines and the requisite changes in existing systems.

\section{Manufacture Sector of Pakistan}

As far as the economy of Pakistan is concerned, manufacture sector is one of the major contributors. This can be understood in the light of the fact that till the year 2015 and 2016 more than $60 \%$ of the country's export was contributed by manufacturing sector. As a matter of fact, the manufacture sector accounts for more than $45 \%$ of total manufacturing and employ around $35 \%$ of total available workforce. The wide spread of Pakistan manufacture sector ranges from small cottage industries to the biggest textile manufacturers in the country, even some of the small and medium size firms are also engaged in the process.

The total gamut of Pakistan textile industry can be divided into several areas:

- Spinning

- Weaving

- Processing, and

- Garment manufacturing

In all the above given sectors, spinning is the oldest segment of the overall industry and in the current scenario there are more than 10 million spindles operating in different parts of the country. As per the reports of PES (Pakistan Economic Survey), 2011 Pakistan holds the five percent of world's spinning capacity and eight percent of Asia's capacity. In terms of Textile Vision (2015) and SMD (2016) the Pakistan textile industry has shown tremendous growth in the last two decades and in the present times the country is enriched with several spinning and processing avenues all over the country. As a matter of fact, maximum number of units i.e. 70\% is installed in Punjab, Pakistan. After the removal of quota regime in the industry it has developed by two hundred percent and now is just next to India and China. According to Textile Vision (2015) there are more than 600 processing units in the country and engaged in the acts of dyeing, printing, etc. this is a surprising fact that the $50 \%$ of the total capacity of the country has increased in last 15 years and the share of readymade garments has increased by $35 \%$ and for hosiery accounts for around $30 \%$.

With such a huge development of the industry, it is also true that more than $70 \%$ of the units in the country are in un-organized form and due to this the overall productivity of the sector has also decreased. The agencies have tried a lot to improve the scenario but the assigned budget by the central government was not enough to re vamp the unorganized units engaged in textile sector. By the year 2015 the synthetic textile industry has been grown to a level of $52 \%$ and if the respective governments join hands to given assisting policies then the textile industry is liable to become the major contributor in GDP of the country. Then on one hand the Pakistani textile industry is struggling of right policies and development spree and on the other hand the textile exports are under surveillance for dumping activities. This is a well-known fact that the economy of Pakistan is a developing economy and has been caught in the cross current of globalization, international agencies like WTO has tried a lot to improve the situation but then again the internal political and economic structure is not supportive enough for the textile industry to flourish. According the Ahmad (2016) the quality of cotton grew in Pakistan in better than any other neighboring country i.e. China, India, etc. the uniformity and shine of this cotton is matchless. Here it is important to mention that the low-end cotton is used for making items like towels, beddings and other related products. In the country itself it is giving a tough competition to foreign products and if the same is being sold in other countries then it will become the market leader in minimum given time.

Apparently, the countries like Afghanistan, India, China, etc. can be the most prospective customers.

This is the major point in question that with such good quality products and raw material, why the country is not able to develop the textile industry to its deserving state. Many of the earlier researcher have contributed in the field i.e. Khan (2015) ; PES (2017); Ali (2014) stated that if the Pakistan is able to improve the quality standards, then certainly there is a clean chance for the industry to flourish and reach the top position. The textile industry of the country is not yet customer centric and the focus is on manufacturing and sales, as stated above the application of quality standards is in proximity 
with the customers and rely on the type and kind of demands raised by them.

Main objective and goal of this research is determination of significant factors affecting implementation of ISO in manufacturing sector at Pakistan

\section{Literature review}

fueled with the best available raw material the country is not able to sell in home country and is forced to export maximum of its produce. This is just a matter of false business philosophy; the economic planners are really interested in reviving the manufacture industry then the quality confirmations are necessary to be followed.

Ahmed et al (2015), stated that the overall business performance is very closely related to the performance of exports in the country. This is because of the reason that exports are liable to attract foreign currency and the same is having a positive role to play in the development of overall economy.

In case of textile industry of Pakistan, export orientation is there but then again, this dimension is being invested for export dumping. As of now there are only a few countries that are regular customers and due to non-maintenance of international quality standards other countries are not willing to join hands.

Terziovski et al (2015), Conducted a study on the growth and development of manufacture industry in European countries. 123 large and medium scale companies were included in the study and findings of the study stated that in Europe the textile industry is producing on an advance level but then again due to the lack of quality confirmation and suppressed export orientation it is not able to contribute to the economic well-being of the country.

The common finding was that, most of the manufacture firms were not following the international quality standards and because of the same preference and taste of the customer is overlooked. If only $30 \%-40 \%$ of the textile companies start to follow these international
Khan (2013), conducted a study on the current competitive situation of Pakistan textile industry and stated that in the present times the textile industry is offering the finished products based on manufacturing schedules and not according the demand of the customers. This means that most of the firms are not working in confirmation with the international quality standards and this is the only reason that even being guidelines, then more than $70 \%$ of the manufacture produce will be absorbed in the country itself.

Singhal et al (2016), stated that there are a number of lacunas in the basic orientation of textile industry all over the world; it is evident from a number of studies that more than $30 \%$ of the global textile business in running in unorganized manner and even the rest $70 \%$ is also affected by the same. The researchers suggested an excellence model where the thrust is given on the development of the textile firms at the bottom of the pyramid and join them to mainstream business. They also stated the business model of India and China where the government has directly included the Micro, Small and Medium firm to mainstream business functions. As a matter of fact the produce of small firms is considered as semi-finished products of other larger firms, in this way the small firms will get the appropriate price of their products and the larger firms will be able to install the benchmarking systems like ISO in their systems. This is certainly going to benefit the business scenario all over the world.

\section{Research methodology}

Research methodology for this study was qualitative approach. Previous studies were carried in depth which helped to determine 29 common factors which barriers in implementation of ISO in manufacture sector. On basis of identified factors, a questionnaire was set and disbursed among 30 highly qualified experts for reliability and validity of the questionnaire. Value of Cronbach's alpha was 0.94 . Reliability test and validity helped to finalize the actual survey.

Actual survey was conducted among experts of manufacture sector for determination of significant factor which causes barrier in implementation of 
ISO 9001:2015 in Pakistan manufacture sector of Pakistan. In total 236 responses were received back from experts with correct information and response. Respondents were having minimum academic qualification of bachelor's and Master's in the field of management Table 1 shows identified factors which causes barrier and also affects the implementation of ISO 9001:2005 throught out the world.

Table 1: Common factors

\begin{tabular}{|c|c|c|c|}
\hline $\begin{array}{l}\text { 1. Top management } \\
\text { leadership }\end{array}$ & 9. Resistance by employees & 17. Preparation to top management & $\begin{array}{l}\text { 25. Insufficient knowledge in } \\
\text { quality }\end{array}$ \\
\hline 2. Requirements of ISO & $\begin{array}{l}\text { 10. Commitment by top } \\
\text { management }\end{array}$ & 18. Financial resources & $\begin{array}{c}\text { 26.Absence of consulting } \\
\text { boards }\end{array}$ \\
\hline 3. Employees training issues & 11. Internal audits & 19.Collaboration among Industries & 27.Credibility of the industry \\
\hline 4. Production Training & 12. Industrial issues & 20. Unwillingness to make changes & 28.Insufficient resources \\
\hline $\begin{array}{l}\text { 5. Inadequate Human } \\
\text { Resources }\end{array}$ & 13. Complexity in industries & 21. quality standards & $\begin{array}{l}\text { 29. No coordination of } \\
\text { internal sections }\end{array}$ \\
\hline 6. Process of orientation & $\begin{array}{l}\text { 14. issues of Quality } \\
\text { Guidelines }\end{array}$ & 22.Departmental issues & \\
\hline $\begin{array}{l}\text { 7.Resources of new } \\
\text { technology }\end{array}$ & $\begin{array}{l}\text { 15. Inflating the size of } \\
\text { documents }\end{array}$ & 23. ISO importance & \\
\hline $\begin{array}{l}\text { 8. Training to all employees } \\
\text { of company }\end{array}$ & 16. Organizational culture & 24.Insufficient knowledge & \\
\hline
\end{tabular}




\section{Data Analysis}

Data from actual survey was collected from the respondents was interrupted and analyzed with help of Mean value. SPSS version 27 was used for this research. Factors which have value of 4 or above are known as significant factors (Sohu et al., 2018). In this study, factors having mean value more than 4 are selected as significant factors. Table 2 represents the results of the actual survey with Mean value.

Table 2: Significant Factors with Score of Mean value

\begin{tabular}{|l|c|}
\hline Factor & Mean Value \\
\hline 1. Employees training issues & 4.871 \\
\hline $\begin{array}{l}\text { 2. Commitment by top } \\
\text { management }\end{array}$ & 4.791 \\
\hline 3. Resistance by employees & 4.724 \\
\hline $\begin{array}{l}\text { 4. Collaboration among } \\
\text { Industries }\end{array}$ & 4.628 \\
\hline $\begin{array}{l}\text { 5. Financial resources } \\
\text { 6. Insufficient knowledge in } \\
\text { quality }\end{array}$ & 4.607 \\
\hline $\begin{array}{l}\text { 7. No coordination of } \\
\text { internal sections }\end{array}$ & 4.502 \\
\hline 8. Process of Orientation & 4.385 \\
\hline $\begin{array}{l}\text { 9. Inadequate Human } \\
\text { Resources }\end{array}$ & 4.349 \\
\hline $\begin{array}{l}\text { 10. Absence of consulting } \\
\text { boards }\end{array}$ & 4.291 \\
\hline $\begin{array}{l}\text { 11.Leadership by top } \\
\text { management }\end{array}$ & 4.184 \\
\hline
\end{tabular}

\section{Conclusions}

On the basis of facts and figures discussed and assessment done by the researcher it is clear that the certification of ISO 9001 is quintessential in manufacturing sectors at Pakistan and not in Pakistan only all the firms around the globe should have the standardization and process of benchmarking their own business. This research has concluded that there are 11 eleven factors which are highly causing the barriers in the implementation of ISO 9001-2015 in manufacture sector at Pakistan. This research will be very much helpful for the top managerial staff of the manufacture sector to control these eleven factors which causes barriers in implementation of ISO 9001:2015.

\section{References}

[1] Memon, N. H., Abro, Q. M., \& Memon, Z. A. (2011). ISO in the construction and manufacturing companies: A case study from the construction industry of Hyderabad and Karachi, Pakistan. Mehran University Research Journal of Engineering \& Technology, 30(2), 339-348.
[2] Boer, H., Gerolamo, M. C., Jorgensen, F., \& Carpinetti, L. C. R. (2015). The relationship between organizational culture and quality techniques, and its impact on operational performance. International Journal of Operations \& Production Management, 35(10), 1460-1484.

[3] Shafiq, M. (2012). Implementation of quality management systems and business excellence frameworks in Pakistani textile companies. Journal of Quality \& Technology Management, VIII(II), 11-23.

[4] Djofack, S., \& Camacho, M. A. C. (2017). Implementation of ISO 9001 in the Spanish tourism industry. International Journal of Quality \& Reliability Management, 34(1), 1837.

[5] Morris, A. S. (2003). ISO 14000 Environmental management standards: Engineering \& financial aspects. John Wiley, London.

[6] Arena, M., Azzone, G., \& Platti, M. (2012). ISO14001: Motivations and benefits in the Italian metal industry. International Journal of Engineering Business Management, 4(41), 1-9.

[7] Kelepile, K. (2015). Impact of organizational culture on productivity and quality management: A case study in diamond operations unit, DTC Botswana. International Journal of Research in Business Studies and Management, 2(9), 35-45.

[8] Puvanasvaran, P., Tian, R. K. S., \& Vasu, S. (2014). Lean environmental management integration system for sustainability of ISO 14001:2004 standard implementation. Journal of Industrial Engineering and Management, 7(5), 1124-1144.

[9] Domingues, P., Sampaio, P., \& Arezes, P. M. (2017). Management systems integration: Survey results. International Journal of Quality \& Reliability Management, 34(8), 1252-1294.

[10] Gaureanu, A., Weinschrott, H., Dumitrescu, C. D., \& Jitarel, A. (2016). Quality management and occupational safety and health effects on organization's sustainable development, Managing innovation and diversity in knowledge society through turbulent time, presented at MakeLearn \& TIIM conference, Timisoara City, 2016, Timisoara, Romania: ToKnowPress.

[11] Fonseca, L. (2015). ISO 14001:2015: An improved tool for sustainability. Journal of Industrial Engineering and Management, 8(1), 37-50.

[12] ISO Central Secretariat (2019). The ISO 9001 family of international standards, Switzerland. 
https:// www.iso.org/about-us.html. Retrieved on January 4, 2019.

[13] Collins, K. M. T., Onwuegbuzie, A. J., \& Sutton, I. L. (2006). A model incorporating the rationale and purpose for conducting mixed methods research in special education and beyond. Learning disabilities: A Contemporary Journal, 4(1), 67-100.

[14] Anjum, M. N., \& Imran Ullah (2016). ISO certifications: Trends and scope in Pakistan. European Journal of Business and Management, 8(10), 81-89.

[15] Ataullah, M. A., Sajid, A., \& Khan, M. R. (2014). Quality related issues and their effect on return of Pakistan textile industry. Journal of Quality and Technology Management, X(1), 69-91.
[16] Debby, W., Vaughan, C., \& Trigunarsyah, B. (2015). Examining the implementation of ISO 9001 in Indonesian construction companies. The TQM Journal, 27(1), 94-107.

[17] Galetto, M., Franceschini, F., \& Mastrogiacomo, L. (2017). ISO 9001 certification and corporate performance of Italian companies. International Journal of Quality \& Reliability Management, 34(2), 231250.

[18] Sohu, S., Abdullah, A. H., Nagapan, S., Fattah, A., Ullah, K., \& Kumar, K. (2017, October). Contractors perspective for critical factors of cost overrun in highway projects of Sindh, Pakistan. In AIP Conference Proceedings (Vol. 1892, No. 1, p. 080002). AIP Publishing LLC. 